Editorial

\title{
What are the Possibilities of Uterine Transplantation in Transgender Patients?
}

\author{
Quais são as possibilidades de transplante uterino em pacientes \\ transgêneros?
}

\author{
Théo Lerner ${ }^{1}$ Dani Ejzenberg ${ }^{1}$ Elsa Aida Gay de Pereyra ${ }^{1}$ José Maria Soares Júnior ${ }^{1}$ \\ Edmund Chada Baracat ${ }^{1}$ \\ ${ }^{1}$ Faculdade de Medicina, Universidade de São Paulo, São Paulo, \\ SP, Brazil \\ Rev Bras Ginecol Obstet 2017;39:521-522.
}

Currently, there are heated discussions about the linguistic limitations of the binary gender model for the representation of the various forms of gender expression. In Anglo-Saxon countries, the possibility of using gender-neutral articles and pronouns is being discussed, while in our Brazilian population, the gender derivation vowel of pronouns is sometimes substituted by the '@' or ' $x$ ' characters. The proper nomenclature to refer to these people must respect the genre with which they identify themselves. Thus, when referring to an individual born with biological male sex and with female gender identity, we must use the term transgender woman.

Not every transgender individual must necessarily undergo sex reassignment surgery. This must be a particular decision made by each individual in conjunction with the multidisciplinary team following the case, according to Resolution number 208/2009, of the Regional Medical Council of the State of São Paulo, Brazil. The Brazilian Unified Health System (SUS, in the Portuguese acronym), within the principles of universality and integrality, has regulated the necessary conditions for the process of sex reassignment by ordinance number 2836/2011. Nowadays, access to the sexual reassignment process and the adequate follow-up are the main challenges faced by the transgender population, which is estimated to be between $0.3 \%$ and $0.6 \%$ of the general population in the United States. ${ }^{1-3}$

The success of the first uterine transplantation recently performed in our country opens a new field of activity in the area of human reproduction. It may assist women with no possibility of becoming pregnant, such as those with congenital agenesis of the uterus, massive destruction of the endometrium after infected abortion, or those hysterectomized. ${ }^{4}$ However, we still have much to improve in this field before its consolidation as a concrete alternative for these women.

The improvement of this technique should lead to the inevitable question about the possibilities of its application in contexts different from those initially imagined, that is, expanding it to transgender individuals. This hypothesis is certainly a broad question for many researchers. The only historical reference for attempted uterine transplantation in the literature was reported in Germany, in 1931. The transgender woman Lili Elbe underwent uterus transplantation and died after three months due to surgery complications. This fact brought repercussions and discussions both in academia and in the media. It was even portrayed in the film The Danish Girl (2015). ${ }^{5}$ Perhaps, this is a limitation of the technique for uterine transplantation.

Transgender individuals have gender identity that is inconsistent with their biological sex. This disagreement can cause intense psychologic suffering, and has no correlation with preferences or objects of sexual desire. The individual feels dissatisfied with his/her own body, and this feeling is independent from the romantic relationship models experienced. In this scenario, there is a desire for complete transformation, including the possibility of procreation, which is a major dilemma with the existing technology.

Reproductive rights are recognized as universal rights by the Brazilian legislation, including the LGBTT (lesbian, gay, bisexual, transsexual and transgender) population, who have specific rights of access to health as stated by law, among

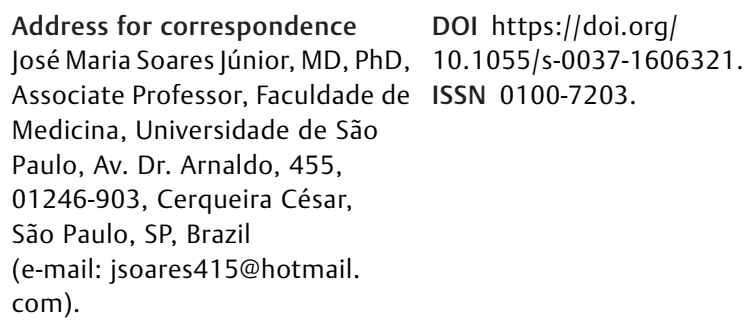

Copyright $\odot 2017$ by Thieme Revinter Publicações Ltda, Rio de Janeiro, Brazil

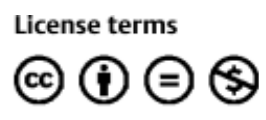


which the recognition of their social name, according to Federal Decree number 8727/2016, ${ }^{6}$ and State Decree - SP number $55588 / 2010 .^{7}$ Article 2 of the LGBTT National Health Policy $^{8}$ has among its specific objectives: to guarantee the sexual and reproductive rights of the LGBTT population within the Brazilian Health System to promote the improvement of technologies used in the sexual reassignment process for women and men; and to conduct studies and research related to the development of services and technologies aimed at the health needs of the LGBTT population. This last objective poses a great challenge, especially regarding uterine transplantation.

In the ethical sphere, Resolution number $2121 / 2015^{9}$ of the Brazilian Federal Council of Medicine regulates assisted reproduction (AR) services in the country and establishes the following: 1) all capable people who request the procedure, and if the indication is not distant from the limits of this resolution, can be recipients of AR techniques, provided that the participants are in full agreement and duly informed in accordance with current legislation; 2) the use of AR techniques is allowed for homosexual couples and single people, respecting the right to conscientious objection by the physician; 3 ) shared gestation is allowed for a homosexual couple with no infertility issues. There is no comment on uterine transplantation in this resolution.

Within the diverse expectations of our society regarding romantic relationships, one of the most prevalent is the formation of a family nucleus that can extend over time. In this context, it is a matter of time until new family structures start to request assistance from health services to achieve this goal. At this point, there is a greater need to discuss new techniques, such as uterine transplantation.

Among the limitations of the uterine transplantation technique is the organ fixation in the abdominal cavity. To this end, round, uterosacral ligaments, and sometimes parametrial ligaments of the recipient woman are used. For a successful implanted gestation, it is necessary to undergo a specific hormone therapy prior to embryo transfer, and throughout pregnancy. Concomitantly, immunosuppressive drugs are critical in preventing the rejection of the transplanted uterus, but they also allow other complications to arise, including opportunistic infections. These are the major challenges to the existing technique. ${ }^{4,10,11}$

In the current context, for the performance of the technique in individuals of male biological sex, great modifications and improvements would be necessary. Anatomical and physiological differences have to be overcome, such as the shape of the male pelvis, which is narrower and has a smaller opening than the female pelvis, and that could hinder the implantation and growth of the uterus during pregnancy. The ligaments used for the fixation of the uterus in the abdominal cavity are non-existing structures in men. The hormonal management prior to embryo transfer and for the maintenance of the pregnancy should also be adapted to the male hormonal profile. The immunosuppressive scheme could be adapted to the transplantation of other organs in men, but there still is no consensus on which scheme is effective in the case of uterine transplantation. There is also the psychological impact of this type of surgery on transgender women. All of these issues require extensive debate and a lot of research time.

In the clinical practice, uterine transplantation is a surgery still performed on an experimental basis that requires further studies before its extension to transgender women. In the current stage of technical development, uterine transplant surgery should not be recommended for transgender women.

Conflicts of Interest

Authors declare no conflict of interest.

\section{References}

1 Harris BC. Likely Transgender Individuals in U.S. Federal Administrative Records and the 2010 Census. Washington, DC: U.S. Census Bureau; 2015

2 Gates GJ. How Many People Are Lesbian, Gay, Bisexual, and Transgender? Los Angeles, CA: The Williams Institute/UCLA School of Law; 2011

3 Flores AR, Herman JL, Gates GJ, Brown TNT. How Many Adults Identify as Transgender in the United States? Los Angeles, CA: The Williams Institute/UCLA School of Law; 2016

4 Soares JM, Ejzenberg D, Andraus W, D'Albuquerque LA, Baracat EC. First Latin uterine transplantation: we can do it!. Clinics (Sao Paulo) 2016;71(11):627-628

5 Hooper T. The Danish Girl. United States: Focus Features; 2015

6 Brasil. Presidência da República. Decreto no 8.727 de 28 abril de 2016. Dispõe sobre o uso do nome social e o reconhecimento da identidade de gênero de pessoas travestis e transexuais no âmbito da administração pública federal direta, autárquica e fundacional. http://www.planalto.gov.br/ccivil_03/_ato2015-2018/2016/decreto/D8727.htm. Acessado Janeiro 10, 2017

7 São Paulo. Assembleia Legislativa do Estado de São Paulo. Decreto no 55.588 de 17 de março de 2010. Dispõe sobre o tratamento nominal das pessoas transexuais e travestis nos órgãos públicos do Estado de São Paulo e dá providências correlatas. http://www.al.sp. gov.br/repositorio/legislacao/decreto/2010/decreto-55588-

17.03.2010.html. Acessado Março 25, 2012

8 Ministério da Saúde. Secretaria de Gestão Estratégica e Participativa. Departamento de Apoio à Gestão Participativa. Política Nacional de Saúde Integral de Lésbicas, Gays, Bissexuais, Travestis e Transexuais. Brasília, DF: Ministério da Saúde; 2013

9 Conselho Federal de Medicina. Resolução CFM no 2.121/2015. Adota as normas éticas para a utilização das técnicas de reprodução assistida. http://www.portalmedico.org.br/resolucoes/CFM/ 2015/2121_2015.pdf. Acessado Junho 11, 2016

10 Ejzenberg D, Mendes LR, Haddad LB, Baracat EC, D’Albuquerque LA, Andraus W. Uterine transplantation: a systematic review. Clinics (Sao Paulo) 2016;71(11):679-683

11 Ejzenberg D, Soares JM, Baracat EC. Uterus transplant: Are we close to this reality? Rev Assoc Med Bras (1992) 2016;62(04): 295-296 